\title{
Dianthus caryophyllus Flower Oil
}

National Cancer Institute

\section{Source}

National Cancer Institute. Dianthus caryophyllus Flower Oil. NCI Thesaurus. Code C107301.

The oil extracted from the flowers of Dianthus caryophyllus. Carnation flower oil is used as a fragrance component. 